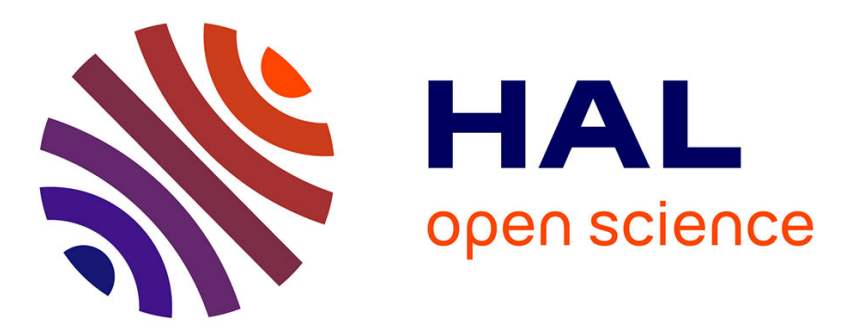

\title{
High elevation of low-relief surfaces in mountain belts: does it equate to post-orogenic surface uplift?
}

\author{
Julien Babault, Stéphane Bonnet, Jean van den Driessche, Alain Crave
}

\section{To cite this version:}

Julien Babault, Stéphane Bonnet, Jean van den Driessche, Alain Crave. High elevation of low-relief surfaces in mountain belts: does it equate to post-orogenic surface uplift?. Terra Nova, 2007, 19 (4), pp.272-277. 10.1111/j.1365-3121.2007.00746.x . insu-00180028

\section{HAL Id: insu-00180028 \\ https://hal-insu.archives-ouvertes.fr/insu-00180028}

Submitted on 17 Oct 2007

HAL is a multi-disciplinary open access archive for the deposit and dissemination of scientific research documents, whether they are published or not. The documents may come from teaching and research institutions in France or abroad, or from public or private research centers.
L'archive ouverte pluridisciplinaire HAL, est destinée au dépôt et à la diffusion de documents scientifiques de niveau recherche, publiés ou non, émanant des établissements d'enseignement et de recherche français ou étrangers, des laboratoires publics ou privés. 


\title{
High elevation of low-relief surfaces in mountain belts:
}

\section{Does it equate to post-orogenic surface uplift?}

\author{
Julien Babault ${ }^{*+\S}$
}

Stéphane Bonnet ${ }^{*}$

Jean Van Den Driessche*

\section{Alain Crave*}

*Géosciences Rennes, Université de Rennes 1, UMR CNRS 6118, Campus de Beaulieu, 35042 Rennes cedex, France.

†now at: Departament de Geologia, Àrea de Geodinàmica Interna, Campus de la Universitat Autònoma de Barcelona, 08193 Bellaterra (Cerdanyola del Vallès), Spain.

${ }^{\S}$ Corresponding author

e-mail: Julien.Babault@uab.es

Phone number: +34935811035

Fax number: +34935811263

Short title:

High elevation of low-relief surfaces in mountains. 


\section{ABSTRACT}

[1] We present experiments of upraising and relaxing topographies showing that peneplanation can occur above the ultimate base level (sea level). After active uplift, the erosion of a topography bounded by a piedmont generates a final smooth and highly elevated topography. Smoothing at high elevation is even possible during active uplift if the evolution of topography is disrupted by the deposition of the products of erosion on its piedmont which is the case at the transition from underfilled to overfilled conditions in foreland basins.

Keywords: relief dynamics, uplift, erosion, sedimentation, denudation, experimental modeling, low-relief, high-level, geomorphic surface, applanation.

\section{INTRODUCTION}

[2] The origin of low relief erosion surfaces lying at high elevation in mountain belts throughout the world has been long debated (e.g. Davis 1911, de Sitter 1952, England \& Molnar 1990, Molnar \& England 1990, Gregory \& Chase 1994, Leonard 2002, McMillan et al. 2002, Molnar 2004). Most previous interpretations have considered that those were remnants of peneplain worn near to sea level, which has been later uplifted by post-orogenic tectonics, then dissected by recent streams (e.g., Davis 1911, Tweto 1975, Epis et al. 1980). An implicit concept to those interpretations is that relief subduing is concomitant with surface elevation lowering near to sea level, and thus remnants of peneplain at high elevation require tectonic uplift to occur. On the other hand, Molnar and England (1990) have proposed that uplift of the peneplain remnants was the isostatic consequence of Pliocene-Quaternary climate-driven dissection, not the cause. But erosion-driven isostatic uplift appears to have a limited effect and cannot account for overall assumed uplift of peneplain remnants from near sea-level to their present elevation (e.g., Gilchrist et al. 1994, Montgomery 1994, Small \& Anderson 1998, Leonard 2002). Alternatively, other works have appealed for deep mantle 
processes to account for large scale uplift of such low-relief surfaces (e.g., Leonard 2002, McMillan et al. 2002).

[3] Several works have recently suggested that piedmont sedimentation in foreland basins corresponds to the rise of the base level for mountain belts erosion, resulting in reducing erosion rate (Baldwin et al. 2003, Babault 2004, Pelletier 2004, Babault et al. 2005a, Carretier \& Lucazeau 2005). In particular, from the relation between piedmont sedimentation and erosion pattern in the Pyrenees during the Cenozoic, Babault et al. (2005b) reach the conclusion that relief subduing does not necessarily equate to surface elevation lowering, so that relief of mountain chains can be smoothed at high elevation. We use a similar experimental approach as Babault et al. (2005a) who have investigated the influence of piedmont sedimentation on the relation between denudation rate and uplift rate of upraising mountain belts. Here, we investigate the effect of piedmont sedimentation on local relief and we describe the mechanisms by which a relief is subdued at high elevation.

\section{EXPERIMENTAL MODELS}

[4] The experimental design we used is the same as described in Babault et al. (2005a). It is made of an erosion box $(600 \times 400 \mathrm{~mm}$ and $500 \mathrm{~mm}$ deep $)$ filled by a material to erode, a silica paste which consists of silica powder $(\mathrm{D} 50=10 \mu \mathrm{m})$ mixed with water $(20 \%)$. The silica paste is uplifted within the erosion box by moving the base of the erosion box, the movements being driven by a screw and a computer controlled stepping motor. In some experiments, a plateau is added at the top of the erosion box, allowing deposition of the eroded products from upstream (herein referred to as "piedmont sedimentation"). The erosion box is located in a rainfall simulator, where four sprinklers deliver a high-pressure water-air mixture ${ }^{*}$. All experiments run under the same rainfall rate of $120 \pm 5 \mathrm{~mm} / \mathrm{h}$, as in experiments in Babault et al. (2005a). To construct $0.5 \mathrm{~mm}$ square-grid digital elevation models, we stop

\footnotetext{
${ }^{*}$ Figure 1 and 2 in supplementary material.
} 
the uplift and rainfall devices every 30 to $60 \mathrm{~min}$. Topographic information is derived from optical stereo data acquired with the Advanced Topometric Sensor developed by the GOM Company.

[5] At first we use the experiments previously performed by Babault et al. (2005a) to analyze the evolution of local relief within a rising zone, without piedmont sedimentation. We also refer to experiment where piedmont sedimentation is allowed after a first phase of erosion of an experimental landscape submitted to constant uplift but without deposition (Babault et al., 2005a). Subsequently, we present new experiments that investigate the effect of piedmont sedimentation on the relationship between the local relief and the mean elevation during a post-uplift decay of the topography. The dynamics of the local relief is studied by analyzing the variation of the mean local slope of the experimental landscapes (within the erosion box), the local slopes being computed over two adjacent pixels of the DEMs in the steepest direction.

\section{Effect of an emergent piedmont on the local relief of an uplifting topography}

[6] The first set of experiments (Babault et al. 2005a) runs under constant uplift and rainfall rates, without piedmont deposition. Different uplift rate values have been applied (5, 10, 15 and $20 \mathrm{~mm} / \mathrm{h}$ ). In each experiment, rills first develop from the borders toward the centre of the erosion box when the mean elevation of the experimental landscapes increases, defining a growth stage of the topography. After $300 \mathrm{~min}$, the mean elevation reaches a constant value defining a macroscale steady state stage for the relief dynamics (Hack, 1960) where the output eroded flux balances the input uplifted flux. The mean elevation $(<h>)$ of the steady state topography increases linearly with the uplift rate $(U)$ (Lague et al. 2003, Babault et al. 2005a). As for the mean elevation vs. uplift rate relationship, the mean local slope $<_{S}>$ increases with $U$ (Fig. 1). 
[7] In a second step, we add a plateau around the steady-state topography (for $U=15$ $\mathrm{mm} / \mathrm{h}$ ) at $t=600 \mathrm{~min}$ and we carry on the experiment at the same uplift and rainfall rates (Fig. 2B). The piedmont sedimentation that starts to surround the uplifted topography induces the onset of the mean elevation growth and the disruption of the previous macroscale equilibrium. Although the uplift and rainfall rates remain continuous, the end of the steady-state at $t=600$ min and the revival of surface uplift mean that the mean denudation does not longer balance the input flux (Fig. 2B) (Babault et al. 2005a). At the local scale, the inhibition of erosion goes with a modification of the local relief. The transversal topographic profiles evolution (Fig. 2A, 2C and 2D) show an increase of the elevations with time, concomitant with a decrease of the local relief. The smoothing of the upraising topography starts downstream and propagates upwards. At $t=615 \mathrm{~min}$, the topography is only smoothed in the downstream parts (Fig. 2C) whereas the local relief of the upstream parts is not modified until $t=630 \mathrm{~min}$ (Fig. 2D).

[8] The piedmont deposition raises the limit between the erosion zone and the deposition zone, i.e. the base level for erosion. As a result, the uplifted zone rises at a relative uplift rate $\left(U_{\mathrm{r}}\right)$ that depends on the aggradation rate $\left(U_{\mathrm{f}}\right)$ (Babault et al. 2005a). Since the onset of the piedmont sedimentation, the relative uplift rate decreases from the initial value of $U=$ $15 \mathrm{~mm} / \mathrm{h}$ down to $U=10 \mathrm{~mm} / \mathrm{h}$ (Fig. 2B). As the local slopes depend on the uplift rate (Fig. 1), the decrease of the relative uplift rate then induces the smoothing of topography ${ }^{\dagger}$. It is also responsible for the decrease of the local denudation rates (Figure 3$)^{*}$, before and after the onset of the piedmont sedimentation. Figure 3 also shows that the subdued topographies are erosional surfaces, i.e. smoothing does not result from the infill of the depressions by erosion products but from lowering of valley slopes by erosion (except between 600 and 615 min and

\footnotetext{
${ }^{\dagger}$ Figure 3 in supplementary material.

Figure 4 in supplementary material.
} 
only for the channelised downstream parts). It is to note that the ongoing uplift leads eventually to a dynamic equilibrium of the topography, characterized by a progressive reincrease of the local relief as the piedmont aggradation rate decreases (see Babault et al. 2005a).

\section{Effect of piedmont deposition on mean elevation dynamics following the cessation of active uplift}

[9] In this new set of experiments, we first look at the evolution of the topographic decay of a previous steady state topography with free borders (Figure 4). At $t=0$ the denudation is at equilibrium with $U=15 \mathrm{~mm} / \mathrm{h}$ and afterwards the experiment runs without uplift. Figure 4 shows the decay of both the mean elevation $\left\langle h>\right.$ and the mean local slope $<_{S}>$ from the initial steady state topography to the final relaxed one. The mean elevation evolves following an exponential decay of the form:

$$
y=y_{0}+C e^{-x / \tau}
$$

with $y_{0 \text { free }}=6.4 \mathrm{~mm}, C_{\text {free }}=15.4$ and $\tau_{\text {free }}=90 \mathrm{y}^{-1}\left(\mathrm{r}^{2}=99.5 \%\right)$.

We perform another relaxation experiment but we add a plateau just after uplift is stopped, allowing piedmont sedimentation to develop. The pattern of the decay of topography is similar to the previous experiment with free borders, the respective value of the terms of equation (1) being:

$$
y_{0 \text { piedmont }}=11.8 \mathrm{~mm}, C_{\text {piedmont }}=8.2 \text { and } \tau_{\text {piedmont }}=100 \mathrm{y}^{-1}\left(\mathrm{r}^{2}=98 \%\right)
$$

The value of the mean local slope at infinite time is similar in both experiments (Fig. 4, ${ }_{s}>_{\text {final }} \sim 3.5^{\circ}$ ), but a main difference exists that is the much higher final mean elevation reached in the experiment with piedmont $\left(y_{0 \text { piedmont }}=11.8 \mathrm{~mm}\right)$ compare to the experiment with free borders $\left(y_{0 \text { free }}=6.4 \mathrm{~mm}\right)$. This difference in elevation $(5.4 \mathrm{~mm})$ almost corresponds to the elevation of the fan apex at $t=425 \mathrm{~min}\left(<h>_{\mathrm{f}}=6.5 \mathrm{~mm}\right)$. 


\section{DISCUSSION}

[10] Numerical modeling and laboratory experiments have already stressed the effect of piedmont deposition, on time scale of mountain denudation and erosion dynamics in mountain catchments, as corresponding to the rise of the efficient base level of mountain belts (Pelletier 2004, Babault et al. 2005a, Carretier \& Lucazeau 2005). In the present work we focus on this effect with regard to the local relief in mountain belts.

[11] The experiments show that relief subduing, which corresponds to local slope decrease, may develop during the new growth stage of an uplifting topography initially at steady state in response to the development of an aggrading piedmont. They also shows that the development of a piedmont during relief decay induces relief subduing at high elevation, the value of which is a function of the final elevation reached by the piedmont apex. In both types of experiments, relief subduing results from the rise of the efficient base level of the uplifting topography.

[12] The dominating process by which the peneplanation develops is most probably a hybrid process between detachment-limited and transported-limited models. Indeed, in this type of experiments, local slopes and mean elevation decrease with increasing precipitation rates. A detachment-limited process predicts an inverse correlation suggesting that the rate limiting process governing the evolution of the experimental channels is the transport of sediments rather than the rate of bed incision (Turowski et al. 2006). However the upward migration of the topography smoothing argues for a rather advective process, not a diffusive one as predicted by a transported-limited model. Note that hybrid-type numerical model encompasses these two-end members of landscape evolution model by introducing a varying transfer distance. This suggests that the transfer distance may vary during experimental peneplanation but this remains to investigate. More importantly, in both transport-limited and detachment-limited model slope depends on the uplift rate. Hence the decrease of the relative 
uplift rate triggered by piedmont aggradation should allow the development of a peneplain as well in both end-members.

[13] The direct application of the experimental results to natural systems is not reliable, as perfect scaling of laboratory-scale reliefs is nearly impossible (Crave et al. 2000, Hasbargen \& Paola 2000, Lague et al. 2003, Bonnet \& Crave 2006). However, results from modeling can be used to emphasize general concepts of landscape behavior (Bonnet \& Crave 2006). Here, the experimental results provide an alternative explanation in the long-standing debate on the origin of high-elevation, low-relief surface remnants observed in several mountain belts throughout the world, including the Southern Rocky Mountains, the Pyrenees, the Atlas (e.g. Davis 1911, Birot 1937, Choubert 1945, de Sitter 1952, Scott 1975, Molnar \& England 1990). Most interpretations consider that uplift, whatever its origin is, is required to explain the high elevation of low-relief surface remnants that are supposed to have developed near sea-level. Isostatic rebound resulting from heterogeneous erosion or thermal mantle anomaly may also account for post-orogenic uplift (e.g. Molnar \& England 1990, Leonard 2002, McMillan et al. 2002, Molnar 2004, Teixell et al. 2005), but not for the whole elevation in most cases. For example, paleobotanical data show that the present-day elevation of the low-relief surfaces in the Southern Rocky Mountains was nearly the same as during the Late Eocene, suggesting that these surfaces formed at high elevation (Gregory \& Chase 1994, Wolfe et al. 1998). On the other hand, according to Babault et al (2005b), the example of the Pyrenees strongly argues for relief subduing at high elevation during post-orogenic decay as shown by the second set of experiments. Indeed, neither post-Pyrenean tectonics nor mantle thermal anomaly exist that can explain the uplift of low-relief surfaces in this example (Babault et al. 2006). As well, Pliocene-Quaternary, erosionally driven isostatic rebound does not account either for most of the present-day elevation of these surfaces (Babault 2004, Babault et al. 2005b). 
[14] As mountain belt building is generally accompanied by piedmont aggradation, this suggests that relief subduing at high elevation is most likely an intrinsic erosional process to post-orogenic decay of mountain belts.

\section{ACKOWLEDGMENTS}

We thank Jean-Jacques Kermarrec and Jean-Pierre Caudal-Robin for making the experimental apparatus in working order; Philippe Davy for providing the GridVisual soft for experimental topographies display. The manuscript benefited from thorough comments by Sierd Cloetingh and an anonymous reviewer. This research was funded by the CNRS-INSU research program PNSE and ATI. The Ministère de l'Éducation Nationale, de la Recherche et de la Technologie funded Julien Babault's Ph.D. thesis.

\section{REFERENCES CITED}

Babault, J., 2004. Dynamique de l'érosion dans une chaîne de montagnes : Influence de la sédimentation de piedmont. L'exemple des Pyrénées. PhD, Université de Rennes1, Rennes (France), 218 pp.

Babault, J., Bonnet, S., Crave, A. \& Van Den Driessche, J., 2005a. Influence of piedmont sedimentation on erosion dynamics of an uplifting landscape: An experimental approach. Geology, 33, 301-304, doi: 10.1130/G21095.1.

Babault, J., Van Den Driessche, J., Bonnet, S., Castelltort, S. \& Crave, A., 2005b. Origin of the highly elevated Pyrenean peneplain. Tectonics, 24, TC2010, doi:10.1029/2004TC001697.

Babault, J., Van Den Driessche, J., Bonnet, S., Castelltort, S. \& Crave, A., 2006. Reply to comment by Yanni Gunnell and Marc Calvet on "Origin of the highly elevated Pyrenean peneplain”. Tectonics, 25, TC3004, doi:10.1029/2005TC001922. 
Baldwin, J. A., Whipple, K. X. \& Tucker, G. E., 2003. Implications of the shear stress river incision model for the timescale of postorogenic decay of topography. Journal-ofgeophysical-research, 108, ETG7.1-ETG7.17; 5.

Birot, P., 1937. Recherches sur la morphologie des Pyrénées orientales franco-espagnoles. Doctorat Ès Lettres, Faculté des Lettres de l'Université de Paris, Paris, 318 pp.

Bonnet, S. \& Crave, A., 2006. Macroscale dynamics of experimental landscapes. In: Analogue and Numerical Modelling of Crustal-Scale Processes (S. J. H. Buiter \& G. Schreurs eds.). Journal of the Geological Society of London, Special Publications, 253. The Geological Society of London, London, 327-339.

Carretier, S. \& Lucazeau, F., 2005. How does alluvial sedimentation at range fronts modify the erosional dynamics of mountain catchments? Basin Research, 17, 361-381.

Choubert, G., 1945. Note Préliminaire sur le Pontien au Maroc (Essai de synthèse orogénique du Maroc Atlasique). Bull. Soc. géol. France, 5, 677-764.

Crave, A., Lague, D., Davy, P., Kermarrec, J., Sokoutis, S., Bodet, L. \& Compagnon, R., 2000. Analogue Modelling of Relief Dynamics. Physics and Chemistry of the Earth, Part A: Solid Earth and Geodesy, 25, 549-553.

Davis, W. M., 1911. The Colorado Front Range, a study on physiographic presentation. Ann. Assoc. Am. Geogr., 1, 21-83.

de Sitter, L. U., 1952. Pliocene uplift of Tertiary mountain chains. American Journal of Science, 250, 297-307.

England, P. \& Molnar, P., 1990. Surface uplift, uplift of rocks, and exhumation of rocks. Geology, 18, 1173-1177. 
Epis, R. C., Scott, G. R., Taylor, R. B. \& Chapin, C. E., 1980. Summary of Cenozoic geomorphic, volcanic and tectonic features of central Colorado and adjoining areas. In: Colorado Geology (H. C. Kent \& K. W. Porter eds.). Rocky Mountain Association of Geologists, Denver, Colorado, United States, 135-156.

Gilchrist, A. R., Summerfield, M. A. \& Cockburn, H. A. P., 1994. Landscape dissection, isostatic uplift and the morphologic development of orogens. Geology, 22, 963-966.

Gregory, K. M. \& Chase, C. G., 1994. Tectonic and climatic significance of a late Eocene lorelief, high-level geomorphic surface, Colorado. Journal of Geophysical Research, 99, $20,141-20,160$.

Hasbargen, L. E. \& Paola, C., 2000. Landscape instability in an experimental drainage basin. Geology, 28, 1067-1070.

Lague, D., Crave, A. \& Davy, P., 2003. Laboratory experiments simulating the geomorphic response to tectonic uplift. Journal of geophysical research, 108, ETG3.1-ETG3.20; 2.

Leonard, E. M., 2002. Geomorphic and tectonic forcing of late Cenozoic warping of the Colorado piedmont. Geology, 30, 595-598.

McMillan, M. E., Angevine, C. L. \& Heller, P. L., 2002. Postdepositional tilt of the MiocenePliocene Ogallala Group on the western Great Plains: Evidence of late Cenozoic uplift of the Rocky Mountains. Geology, 30, 63-66.

Molnar, P., 2004. Late cenozoic increase in accumulation rates of terrestrial sediment: How might climate change have affected erosion rates? Annual Review of Earth and Planetary Sciences, 32, 67-89, doi: 10.1146/annurev.earth.32.091003.143456.

Molnar, P. \& England, P., 1990. Late Cenozoic uplift of mountain ranges and global climate change: chicken or egg ? Nature, 346, 29-34. 
Montgomery, D. R., 1994. Valley incision and the uplift of mountain peaks. Journal of Geophysical Research, 99, 13,913-13,921.

Pelletier, J. D., 2004. Influence of piedmont deposition on the time scale of mountain-belt denudation. Geophysical Research Letters, 31, L15502, doi:10.1029/2004GL020052.

Scott, G. R., 1975. Cenozoic Surfaces and Deposits in the Southern Rocky Mountains. Geol. Soc. Am. Mem., 144, 227-248.

Small, E. E. \& Anderson, R. S., 1998. Pleistocene relief production in Laramide mountain ranges, western United States. Geology, 26, 123-126.

Teixell, A., Ayarza, P., Zeyen, H., Fernandez, M. \& Arboleya, M.-L., 2005. Effects of mantle upwelling in a compressional setting: the Atlas Mountains of Morocco. Terra Nova, 17, 456-461.

Turowski, J. M., Lague, D., Crave, A. \& Hovius, N., 2006. Experimental channel response to tectonic uplift. Journal of Geophysical Research, 111, F03008, doi:10.1029/2005JF000306.

Tweto, O., 1975. Laramide (Late Cretaceous-Early Tertiary) Orogeny in the Southern Rocky Mountains. Geol. Soc. Am. Mem., 144, 1-44.

Wolfe, J. A., Forest, C. E. \& Molnar, P., 1998. Paleobotanical evidence of Eocene and Oligocene paleoaltitudes in midlatitude western North America. Geological Society of America Bulletin, 110, 664-678, doi: 10.1130/0016-7606.

\section{FIGURE CAPTIONS}

Figure 1: Effect of uplift on the local slopes and the local relief of steady state topographies.

The transversal topographic profiles are parallel to the length of the models, at a distance of 
$110 \mathrm{~mm}$ from the border of the uplifted zone. The mean local slope and the local relief increase with the uplift rate. $U$ : uplift rate; $\langle s\rangle$ : mean local slope.

Figure 2: Effect of an emergent piedmont on the local relief of an uplifting topography.

A: DEM of a laboratory experiment. The view corresponds to the topography at $t=645 \mathrm{~min}$ (point "D" in B). The two series of transversal topographic profiles (black lines 1 and 2) on C and $\mathrm{D}$ are located at a distance of $55 \mathrm{~mm}$ and $110 \mathrm{~mm}$, respectively, from the border of the uplifted zone. B: Macroscale evolution of the experiments with free borders $(0<t<600 \mathrm{~min})$ and with a surrounding plateau $(600<t<720 \mathrm{~min})$. Open squares: mean elevation $(<h>)$; open circles: mean fan apex elevation $\left(<h>_{\mathrm{f}}\right)$; grey triangles: mean denudation rate $(D)$; black circles: relative uplift rate $\left(U_{\mathrm{r}}\right)$. C and D: series of topographic profiles located in downstream and upstream parts, respectively. It shows the progressive increase of the elevation and the concomitant smoothing of the topography (from $<_{S}>=23^{\circ}$ at $t=600 \mathrm{~min}$ to $<_{S}>=12^{\circ}$ at $t=$ $720 \mathrm{~min}$ ) from the onset of piedmont sedimentation.

Figure 3: Effect of an emergent piedmont on the local denudation of an uplifting topography.

Local denudation rates are superimposed on the DEM of the topographies of experiments A, $\mathrm{B}$ and $\mathrm{C}$ at $t=600 \mathrm{~min}$, at $t=615 \mathrm{~min}$ and at $t=630 \mathrm{~min}$, respectively (points " $\mathrm{A}$ ", "B" and "C" in Figure 2B). Colored topography, from blue to red, corresponds to increasing denudation rate, green corresponding to sedimentation. It shows the decrease of both the local erosion and local relief that is induced by the piedmont deposition although the uplift and rainfall rates $(15 \mathrm{~mm} / \mathrm{h}$ and $120 \mathrm{~mm} / \mathrm{h}$, respectively) are kept constant during the experiment. The plateau is $250 \mathrm{~mm}$ large (measured from the border of the uplifting zone). Note that except for the topography B, the smoothed topography is an erosional surface, i.e. smoothing is not achieved by the infilling of depressions with the products of erosion.

Figure 4: Effect of piedmont deposition on the mean elevation in relaxation experiments. 
Open squares and black circles: mean elevations $(<h>)$ of relaxation experiments with and without piedmont sedimentation, respectively. Grey open squares: mean fan apex elevation $\left(<h>_{\mathrm{f}}\right)$. Relaxation experiments start from steady state topography. $<_{S}>_{\text {s.s. }}$ is the mean local slope of the steady state topographies for similar uplift and rainfall rates, and $\left\langle_{s}\right\rangle_{\text {final }}$ is the mean local slope of the final topographies. The greater elevation of the smoothed topography surrounded by piedmont almost correlates with the final elevation of the fan apex.

\section{SUPPLEMENTARY MATERIAL FIGURE CAPTIONS}

Figure 1: Drawing of the experimental apparatus that shows the erosion box filled by silica paste and the moveable bottom used to simulate uplift. The erosion box is located within a rainfall simulator where four sprinklers deliver a high-pressure water-air mixture.

Figure 2: Detailed picture of the erosion box at the end of an experiment. The uplifted landscape is surrounded by a piedmont that formed by the aggradation of the products of erosion. Lower left corner: detailed picture of a sprinkler.

Figure 3: Perturbation of a Steady State topography by piedmont deposition. Photos of the experiment and evolution of its: mean elevation $(<h>)$, mean fan apex elevation $\left(<h>_{\mathrm{f}}\right)$, mean denudation $(D)$, relative uplift rate $\left(U_{\mathrm{r}}\right)$ and uplift rate $(U)$. The piedmont sedimentation that starts to surround the uplifted topography (photo and point "D") induces the onset of the mean elevation growth and then the disruption of the previous macroscale equilibrium. At the local scale, the inhibition of erosion goes with a modification of the local relief. A smoothing of the upraising topography starts downstream and it propagates upwards.

Figure 4: Perturbation of a Steady State topography by piedmont deposition. DEMs movie of the experiment and evolution of its: mean elevation ( $<h>$; blue squares), mean fan apex elevation $\left(\langle h\rangle_{\text {f }}\right.$; yellow circles), mean denudation $(D$; green triangles $)$, relative uplift rate $\left(U_{\mathrm{r}}\right.$; red circles) and uplift rate $(U)$. 


\section{Julien Babault Fig 1 .eps}

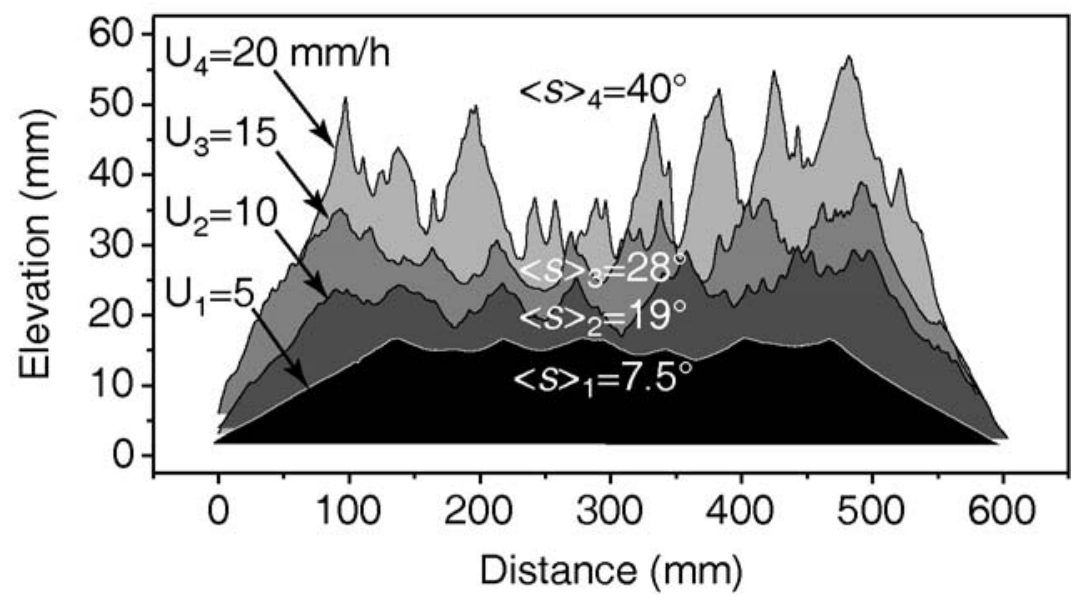

\section{Julien Babault Fig 2 .eps}

A

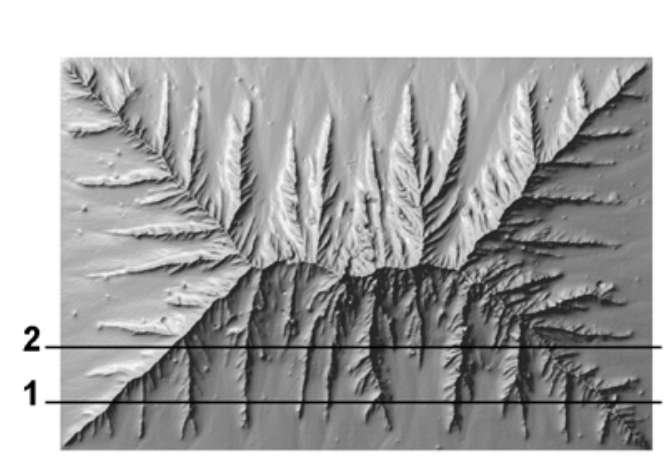

C

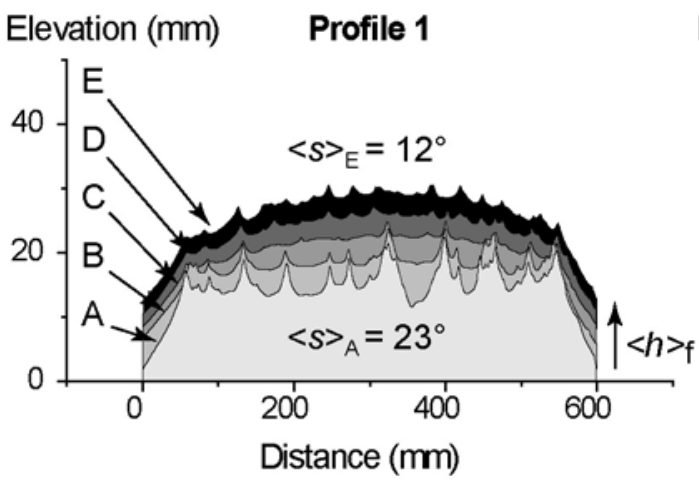

B

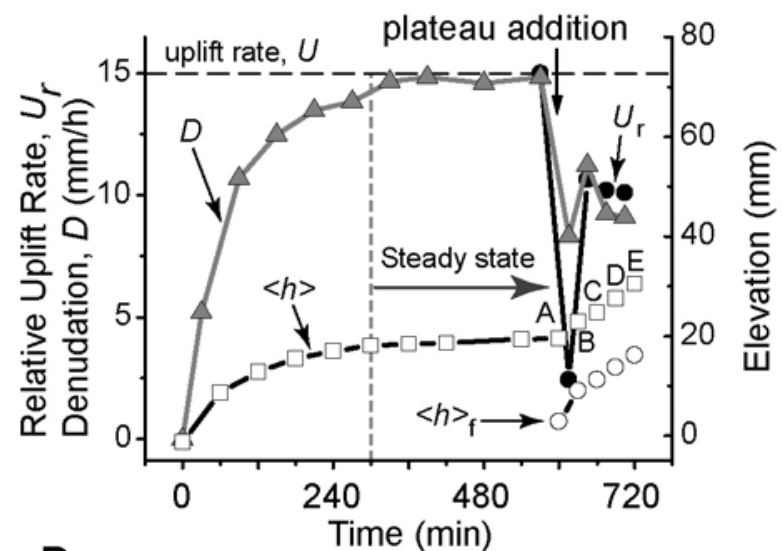

D

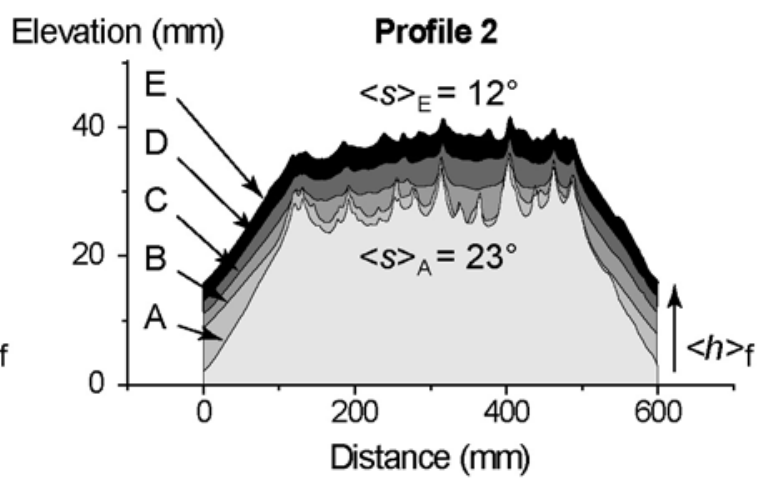


Babault et al. Fig 3 .eps

\section{A. Steady state topography without piedmont deposition}

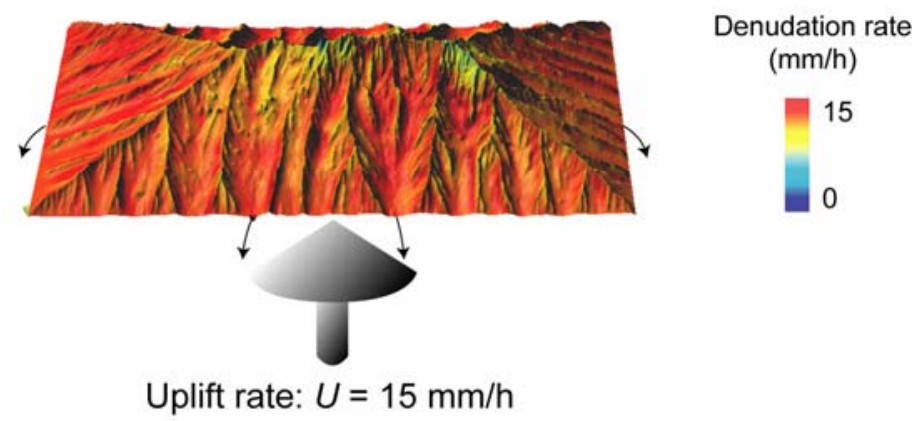

B. Onset of piedmont deposition

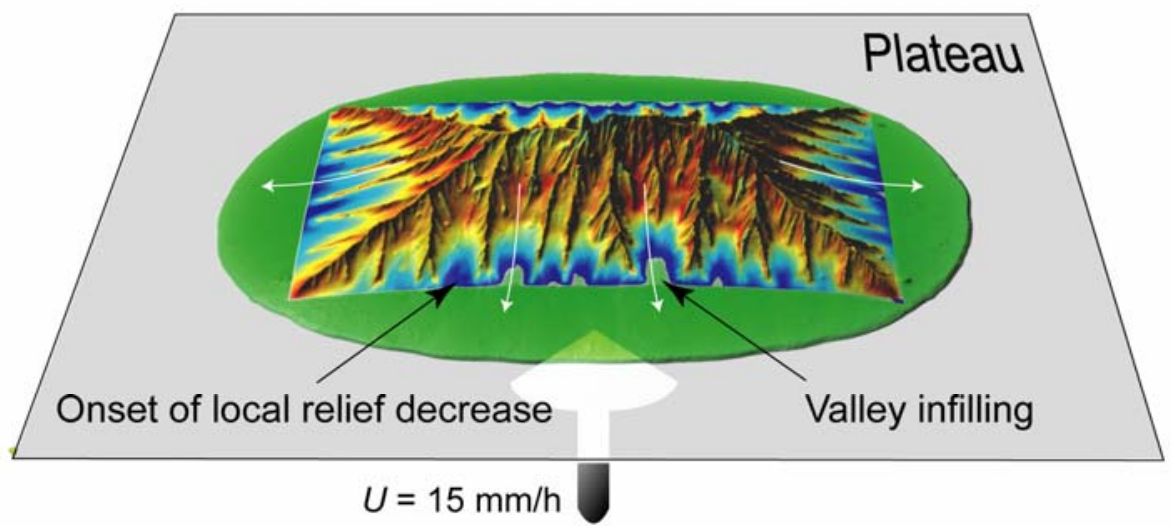

C. Piedmont growth and smooth of the topography

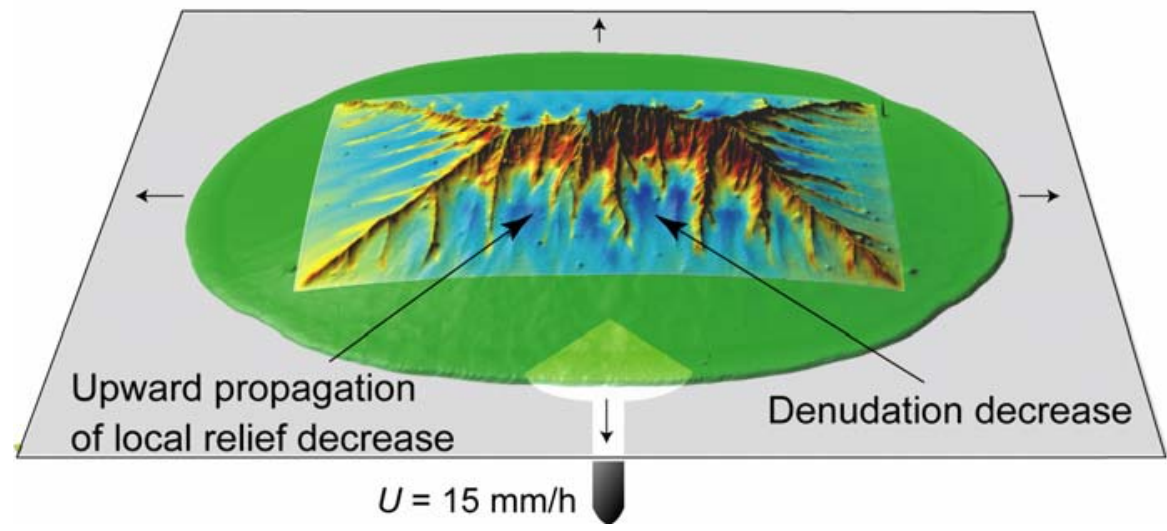


Babault et al. Fig 4 .eps

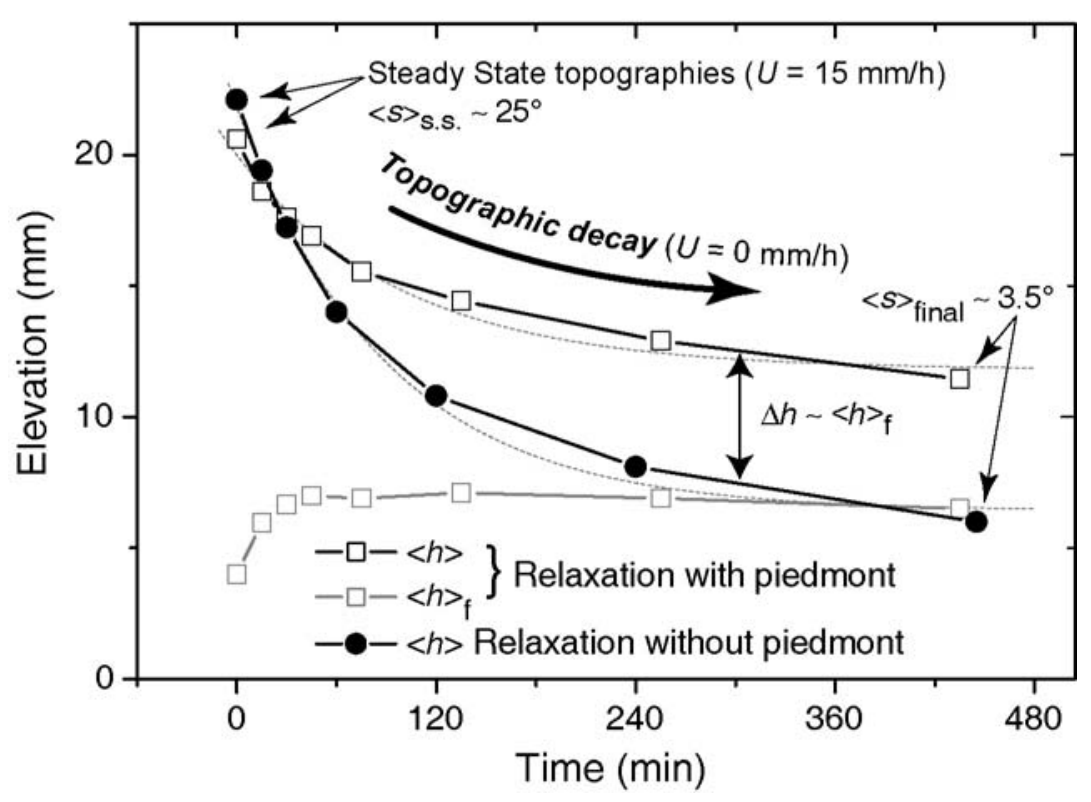


Babault et al. Fig 1 of data repository .eps

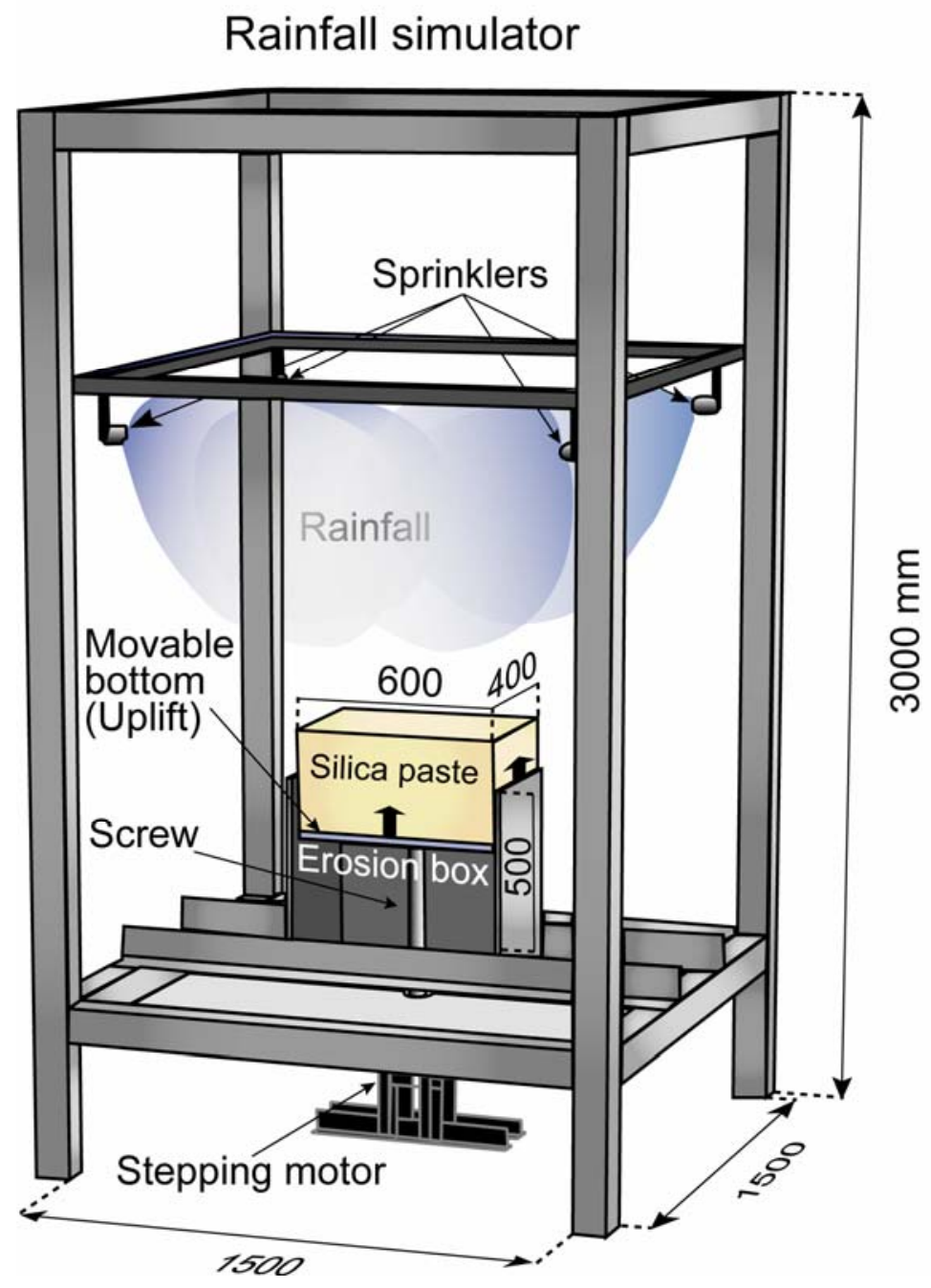

Babault et al. Fig 2 of data repository .tif

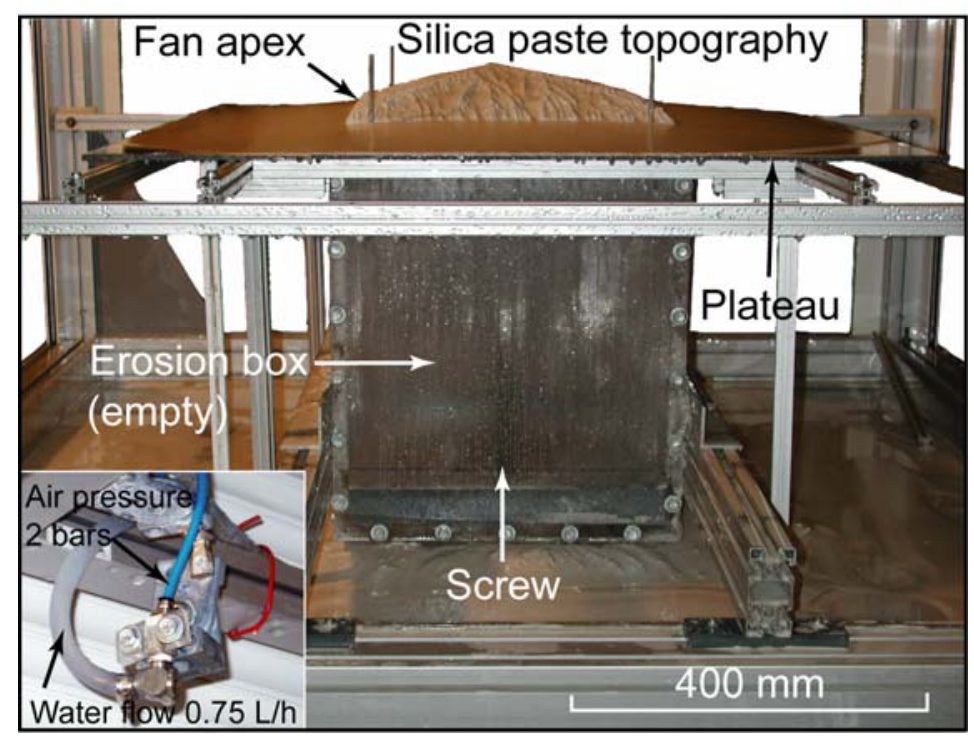

Four figures in Supplementary Material 
Babault et al. Fig 3 of data repository .eps
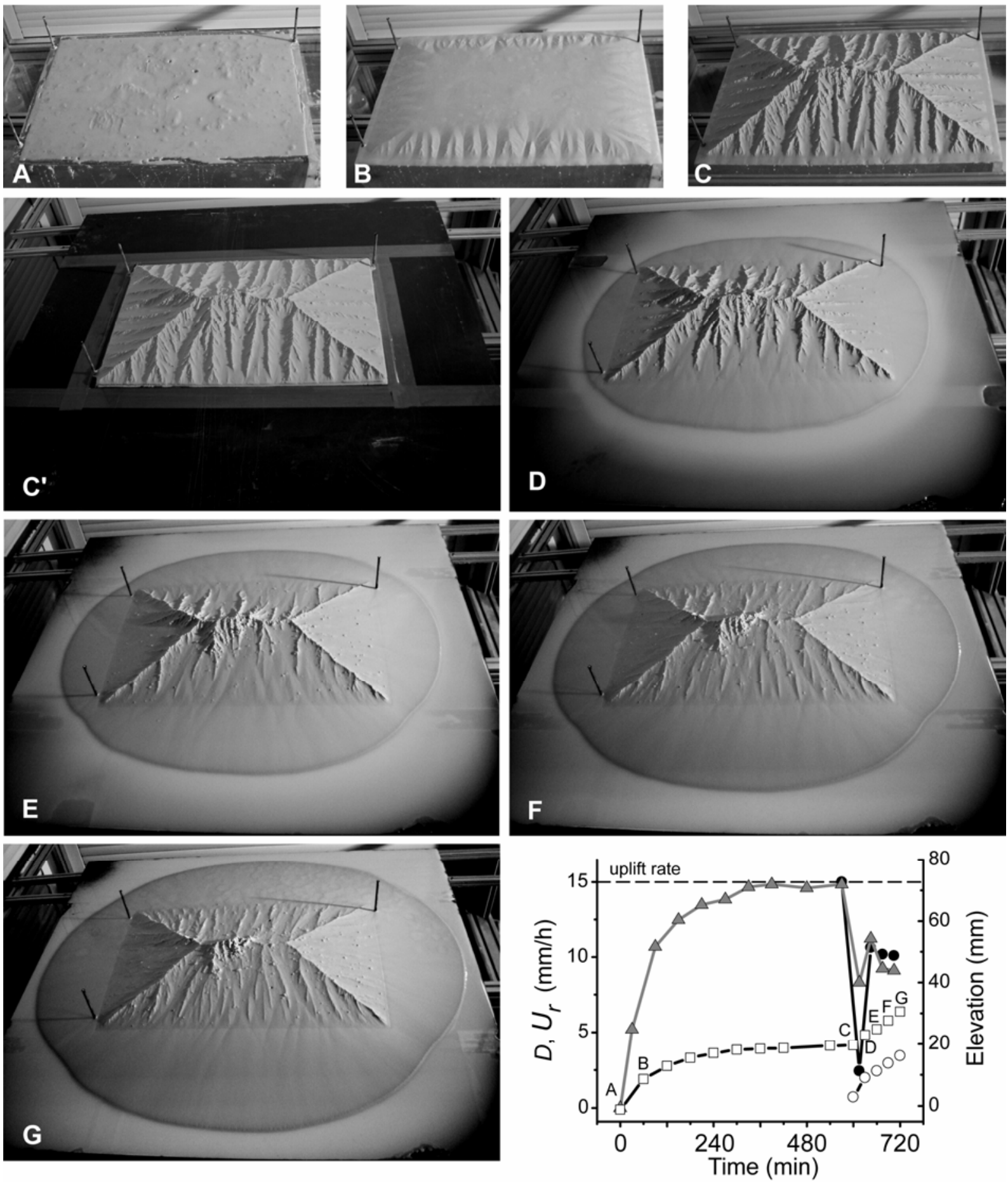

$\rightarrow-<h>$

$\multimap<h\rangle_{f}$

$\triangle-D$

$\rightarrow U_{r}$

$--U$ 


\section{Babault et al, Fig 4 of data repository}
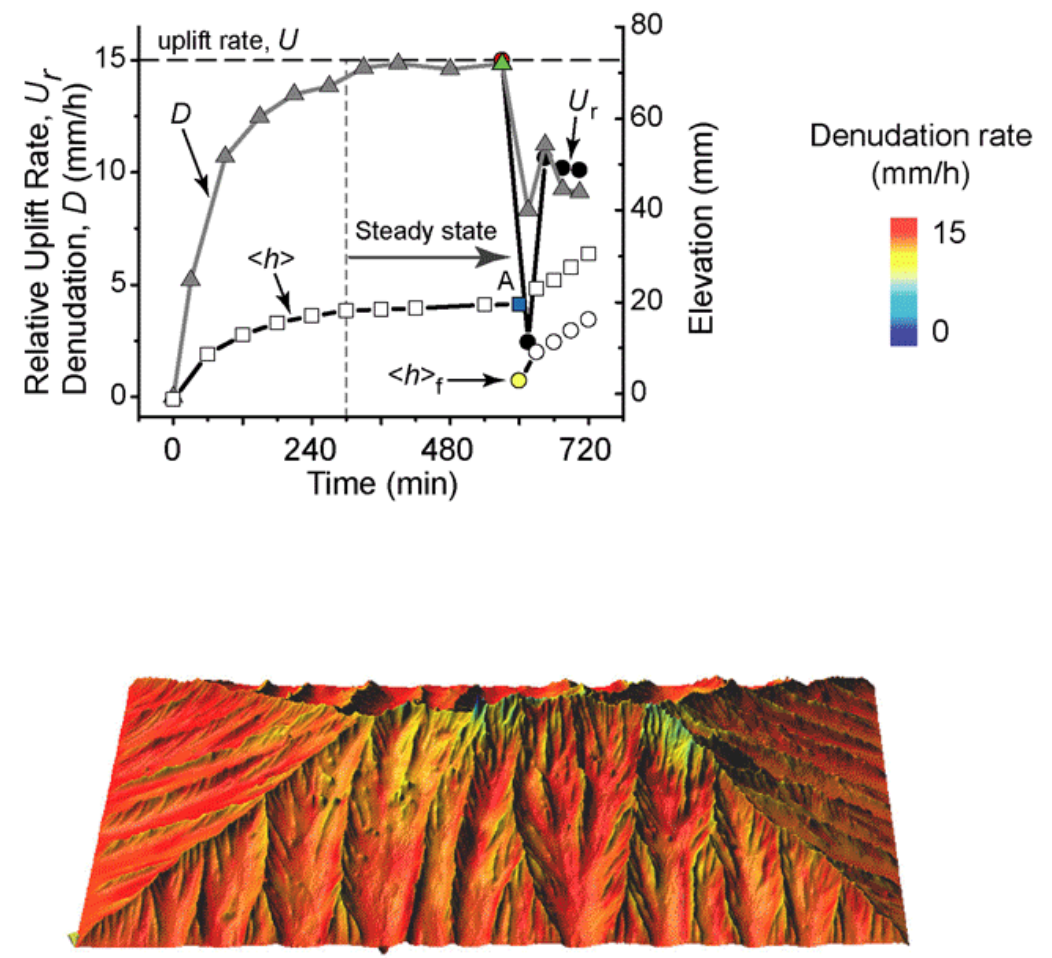